\title{
Individual differences in the sensitivity to serotonergic drugs: a pharmacobehavioural approach using rats selected on the basis of their response to novelty
}

\author{
Michel M. M. Verheij • Jesse V. Veenvliet • \\ Tom Groot Kormelink • Maaike Steenhof • \\ Alexander R. Cools
}

Received: 28 April 2008 / Accepted: 22 April 2009 /Published online: 12 May 2009

(C) The Author(s) 2009. This article is published with open access at Springerlink.com

\begin{abstract}
Rationale The mechanisms underlying individual differences in the response to serotonergic drugs are poorly understood. Rat studies may contribute to our knowledge of the neuronal substrates that underlie these individual differences.

Objectives A pharmacobehavioural study was performed to assess individual differences in the sensitivity to serotonergic drugs in rats that were selected based on their response to a novel environment.

Methods Low responders (LR) and high responders (HR) to novelty rats were tested on the elevated T-maze following systemic injections of increasing doses of various serotonergic agents. The duration of avoidance of the open arms was scored for five trials.

Results The duration of avoidance behaviour was larger in saline-treated LR rats compared to saline-treated HR rats. The 5-HT1A agonist 8-OH-DPAT and the 5-HT2 agonists $\mathrm{mCPP}$ and DOI decreased the duration of avoidance behaviour in LR rats, but increased it in HR rats. The 5HT3 agonist SR57227A and the 5-HT releaser/reuptake inhibitor $d$-fenfluramine increased the duration of avoidance behaviour in both types of rat. However, higher doses of SR57227A were required to alter avoidance behaviour in HR than in LR rats. The onset of the effects of SR57227A, $d$-fenfluramine and WAY100635 was faster in LR than in
\end{abstract}

M. M. M. Verheij $(\bowtie) \cdot J$. V. Veenvliet • T. Groot Kormelink • M. Steenhof · A. R. Cools

Department of Cognitive Neuroscience (CNS), Division of Psychoneuropharmacology (PNF),

Radboud University (RU) Nijmegen Medical Centre, 6525 EZ Nijmegen, P.O. Box 9101, The Netherlands e-mail: M.Verheij@cns.umcn.nl
HR rats. The described effects were receptor specific. A model explaining the data is presented.

Conclusions These data demonstrate that LR and HR rats differ in their sensitivity to serotonergic drugs that act at 5HT3, 5-HT2 and 5-HT1A receptors. The implications of these individual differences for individual-specific treatment of substance abuse are briefly discussed.

Keywords Avoidance behaviour Individual differences . Serotonin pharmacology Serotonergic receptors .

Elevated T-maze $\cdot \mathrm{HR}$ and LR rats

\section{Introduction}

Serotonin (5-hydroxytryptamine, 5-HT) is believed to be involved in the control of a variety of personality traits, including impulsivity, risk taking behaviour (Coccaro 1989; Mehlman et al. 1994) and sensation seeking (Zuckerman 1993, 1996; Netter et al. 1996; Roberti 2004; Pascual et al. 2007). Sensation seeking describes a personality trait characterised by voluntary participation in activities involving personal risk (Zuckerman and Neeb 1979). In humans, individual differences in sensation seeking predict individual differences in vulnerability to psychiatric disorders like depression and schizophrenia (Dervaux et al. 2001; Laget et al. 2006) and to drug abuse (Patkar et al. 2004; Kelly et al. 2006). It has previously been reported that individual differences in the exploratory response to a novel environment in rats can predict their neurochemical and behavioural response to cocaine and amphetamine (Piazza et al. 1989; Hooks et al. 1991, 1992; Cools et al. 1997; Ranaldi et al. 2001; Chefer et al. 2003; Verheij et al. 2008). Moreover, rats that are marked by a differential exploration 
response to novelty have been found to differ in their behavioural response in animal models of schizophrenia (Ellenbroek et al. 1995; Ellenbroek and Cools 2002). On the basis of these and related studies, it has been suggested that enhanced novelty seeking in rats resembles sensation seeking in humans (Dellu et al. 1996; Cools and Ellenbroek 2002; Ballaz et al. 2007a, b, c).

In the present study, we used two types of rat that are known to differ in novelty seeking. Rats that are marked by a high level of exploration in a new environment are labelled high responders (HR) to novelty, whereas rats that are marked by a low level of exploration in a new environment are labelled low responders (LR) to novelty (Cools et al. 1990, 1993; Cools and Ellenbroek 1996, 2002; Cools and Gingras 1998). It has repeatedly been shown that environmental challenges like novelty or pharmacological challenges like cocaine increase accumbal dopamine levels more strongly in HR than in LR rats (Hooks et al. 1991, 1992; Saigusa et al. 1999; Verheij and Cools 2007, 2008; Verheij et al. 2008). Given that serotonergic agents are known to change the release of dopamine (Kilpatrick et al. 1996; De Deurwaerdere and Spampinato 1999; Ichikawa and Meltzer 2000), it is hypothesised that HR and LR rats differ in their sensitivity to these agents. Because individual differences in sensitivity to serotonergic agents have frequently been reported in humans (Lerer and Macciardi 2002; Pickar 2003; Bolonna et al. 2004; Lane et al. 2005; McMahon et al. 2006), rat studies are expected to contribute to our knowledge of the neuronal substrates that underlie these individual differences. In addition, rat studies may help to identify which subjects are sensitive to a particular serotonergic therapy and which subjects are not.

The aim of the present study was to investigate whether HR and LR rats differ in their behavioural response to serotonergic agents. These agents are known to alter the behavioural response on the elevated T-maze. The elevated T-maze consists of one enclosed arm perpendicular to two open arms (Viana et al. 1994). Rats are placed at the distal end of the enclosed arm, and the time to enter one of the open arms (with four paws) is scored. Drugs that mimic the action of serotonin increase the time to approach the open arms (Graeff et al. 1996a, b 1998; Mora et al. 1997; Viana et al. 1997), whereas drugs that block the action of serotonin exert opposite effects (Gargiulo et al. 1996; Mora et al. 1997; Graeff et al. 1998). Behavioural experiments have revealed that the avoidance of the open arms increases after a systemic injection of 5-HT releasers like $d$-fenfluramine (Graeff et al. 1996a, b, 1997), 5-HT3 agonists like SR77227A (Andrews and File 1992) and 5-HT2 agonists like DOI (Peng et al. 2004; Bull et al. 2004) and mCPP (Mora et al. 1997; Graeff et al. 1998; Zangrossi et al. 2001). Interestingly, 5-HT1A agonists like 8-OH-DPAT have been found to increase (Critchley and Handley 1987; Kshama et al. 1990; Treit et al. 1993) or to decrease (Dunn et al. 1989; Collinson and Dawson 1997) avoidance behaviour (see also "Discussion"). Additional experiments have also revealed that the avoidance of the open arms decreases after a systemic injection of 5-HT3 antagonists like ondansetron (Filip et al. 1992; Brioni et al. 1994; Sonavane et al. 2002) and 5HT2 antagonists like ritanserin (Critchley and Handley 1987; Mora et al. 1997; Graeff et al. 1998; Zangrossi et al. 2001). Finally, the 5-HT1A antagonist WAY100635 has been found to increase rather than to decrease the avoidance of the open arms (Collinson and Dawson 1997; Peng et al. 2004).

The present study showed that HR and LR rats indeed differed in their sensitivity to all of the serotonergic agents that are listed above.

\section{Methods}

Animals Adult male Wistar rats (180-220 g at the start of the experiments) were used. These animals were reared in the central animal house of the Radboud University of Nijmegen, The Netherlands. Initially, rats were housed in groups of three per cage in a temperature-controlled environment $\left(20 \pm 2^{\circ} \mathrm{C}\right)$ under a $12 / 12 \mathrm{~h}$ light/dark cycle (lights on at 0730 hours). Food (Ssniff) and water were freely available at all time, except during the open-field and T-maze test (see below). Rats were isolated 3 or 4 days prior to the open-field selection (Cools et al. 1990). The experiments were performed in accordance with institutional, national and international policies on animal care and welfare. All procedures were in agreement with the NRC (National Research Council) 2003 guidelines for the care and use of mammals in neuroscience and behavioural research.

Open-field selection Half an hour before the open-field selection, rats were placed in the experimental room to get accustomed to the new environment. Next, a rat was placed on a novel open field, which consisted of a black table $(160 \times 160 \mathrm{~cm})$ made of Perspex (Cools et al. 1990). The table, which was $70 \mathrm{~cm}$ above the ground, was surrounded by a neutral environment. Light intensity was $170 \mathrm{~lx}$ at the middle of the open field. Once the rat was placed in the centre of the open field, its behaviour was recorded for $30 \mathrm{~min}$ using a computerised automated tracking system as described by Cools et al. (1990). Selection parameters were ambulation and habituation time. Ambulation was defined as the total distance travelled $(\mathrm{cm})$ in $30 \mathrm{~min}$. Habituation time was defined as the period ( $\mathrm{s}$ ) from the start of the selection until the moment the rat showed no locomotor activity for at least $90 \mathrm{~s}$. Rats that habituated in less than $480 \mathrm{~s}$ and walked 
less than 4,800 $\mathrm{cm}$ were classified as LR (Cools et al. 1990, 1997). Rats that habituated in more than $840 \mathrm{~s}$ and travelled more than $6,000 \mathrm{~cm}$ were classified as HR (Cools et al. 1990, 1997). The selection procedure took place between 0900 and 1800 hours. The table was cleaned with $70 \%$ alcohol after each rat.

Elevated T-maze Seven days after exposure to the open field, rats were tested on the elevated T-maze. The elevated T-maze was adapted from the elevated plus-maze (Viana et al. 1994) and the procedure to test our rats (see "Introduction") was slightly modified from Graeff et al. (1996a, b). The arms of the T-maze were of equal dimensions $(50 \times 10 \mathrm{~cm})$. The enclosed arm contained a wall of $40 \mathrm{~cm}$, and the two open arms were surrounded by a rim of $1 \mathrm{~cm}$. The three arms were connected by a central square $(10 \times 10 \mathrm{~cm})$. Light intensity was $2.5 \mathrm{~lx}$ at the central square.

Twenty-five min before the first exposure to the T-maze, rats received a single injection of a particular serotonergic agent or a combination of serotonergic agents (volume, $1 \mathrm{ml} / \mathrm{kg}$, i.p.), whereafter the rats were left undisturbed in their home cage. Different rats were used for each dose of every serotonergic agent or each combination of serotonergic agents. Twenty-five min after the injection, rats were placed at the distal end of the enclosed arm facing the central square, and the time to enter one of the open arms (with four paws) was recorded. The time to avoid the open arms was assessed in each of five consecutive trials (intertrial interval, $10 \mathrm{~min}$ ). All rats were removed from the elevated T-maze once they reentered the enclosed arm. A cut-off time of $600 \mathrm{~s}$ was used. The T-maze was cleaned with $70 \%$ alcohol after each trial. All experiments were performed between 0900 and 1400 hours (Griebel et al. 1993).

Drugs The following drugs were used: 5-HT1A antagonistWAY100635 (N-\{2-[4-(2-methoxyphenyl)-1-piperazinyl] ethyl $\}-N$-(2-pyridinyl)cyclo-hexanecarboxamide trihydrochloride); 5-HT1A agonist-8-OH-DPAT (8-hydroxy-2-(di$N$-propylamino)-tetralin); 5-HT2A/C antagonist-ritanserin (6-[2-[bis(4-flourophenyl)methylene]-1-piperidenyl]ethyl]-7methyl-5H-thiazolo[3,2-a]pyri-midin-5-one); 5-HT2(A)/C agonists-DOI (1-(2,5-dimethoxy-4-iodophenyl)-2-aminopropane) and $\mathrm{mCPP}$ (1-(3-chlorophenyl)-piperazine hydrochloride); 5-HT3 agonist-SR57227A (4-amino-1-(6chloro-2-pyridyl)-piperidine hydrochloride); 5-HT releaser and reuptake inhibitor- $d$-fenfluramine $((+)-N$-ethyl- $\alpha$ methyl- $m$-[trifluoromethyl]-phenethylamine). All these drugs were purchased from Sigma. The 5-HT3 antagonist ondansetron (1,2,3,9-tetrahydro-9-methyl-3-[(2-methyl-1Himidazol-1-yl)methyl]-4H-carbazol-4-one) was purchased from Glaxo. The drugs were chosen because they have been found to affect behaviour in the elevated plus-maze and T- maze (see "Introduction"). To our knowledge, no plus-maze or T-maze experiments have been performed with SR57227A, but it has been shown to produce other behavioural effects at the doses that were applied (Poncelet et al. 1995). All drugs were dissolved in saline. Ritanserin was dissolved in saline with a drop of acetic acid, and the $\mathrm{pH}$ was adjusted with sodium hydroxide (Schreiber et al. 1998; Cayetanot et al. 2001). In order to maintain the levels of stress as low as possible, rats received their injection only once before the first trial and not prior to every trial (Viana et al. 1994; Graeff et al. $1996 a, b)$. In those cases where a particular agonist or antagonist changed avoidance behaviour, a cocktail of this drug with, respectively, an antagonist or agonist (volume, $1 \mathrm{ml} / \mathrm{kg}$, i.p.) was also injected.

Statistical analysis Data were analysed using a two-way ANCOVA with type of rat and treatment as independent factors and trials as a covariate. Where appropriate, this test was followed by a one-way ANCOVA and post hoc LSD analysis. A total number of 511 rats were exposed to the Tmaze. Extreme values (values more than three times the interquartile range) were identified using the explore function of SPSS 12.0.1 and excluded from analysis (Tuinstra et al. 2000). Thirty-eight rats (7\% of the total number of rats) were excluded at one or more trials. The $n$ value (see Figs. 1, 2, 3, 4 and 5) represent the number of rats included on trial 5 (number of rats, 509-38=471). A probability level of 0.05 was considered to be statistically significant.

\section{Results}

Open-field selection The open-field selection procedure revealed 24\% LR $(n=249)$ rats and 25\% HR $(n=260)$ rats. The average distance travelled in $30 \mathrm{~min}$ ( \pm SEM) was $3,624 \pm 88 \mathrm{~cm}$ in LR rats and $8,316 \pm 150 \mathrm{~cm}$ in HR rats. The average habituation time $( \pm$ SEM) was $324 \pm 16 \mathrm{~s}$ in LR rats and $1,310 \pm 29 \mathrm{~s}$ in $\mathrm{HR}$ rats. All efforts were made to include the rats that did not fulfil the criteria $(n=531)$ in other studies (Verheij et al. 2007).

Saline The duration of avoidance of the open arms was larger in saline-treated LR rats than in saline-treated HR rats (Figs. 1, 2, 3 and 4-ANCOVA: type effect, $\left.F_{(1,90)}=28.73, p<0.001\right)$. The duration of avoidance behaviour was similar between the two types of rat during trials 1 and 2 . During the remaining trials, LR rats were marked by more avoidance behaviour than HR rats. This larger increase of avoidance behaviour in LR rats compared to HR rats was also observed under naive conditions (data not shown). 
Fig. 1 Effects of the 5-HT3 agonist SR57227A (a, b), the 5-HT3 antagonist ondansetron (c, d) and the combination of both $(\mathbf{e}, \mathbf{f})$ on the duration of avoidance of the open arms in LR (left) and HR (right) rats. Asterisks Significant change vs saline. Number signs Significant decrease vs SR57227A

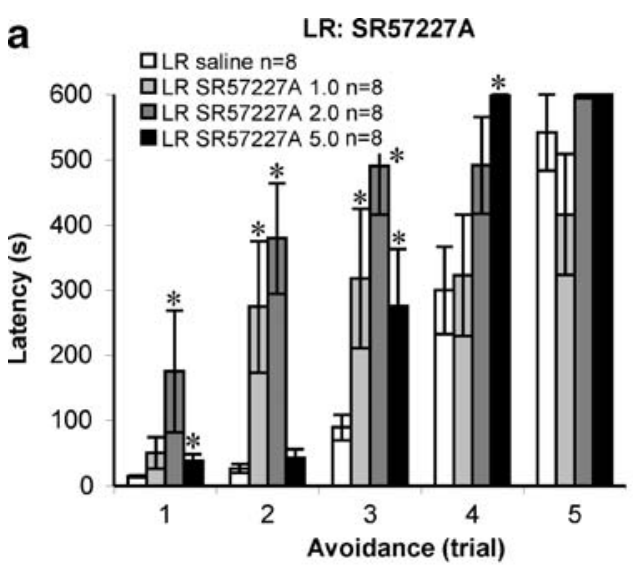

C

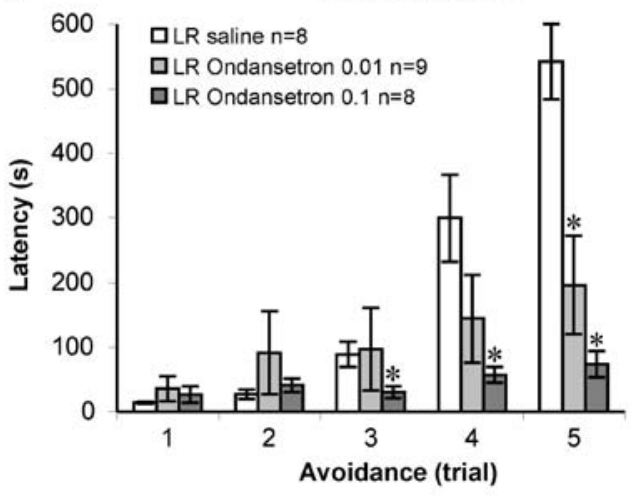

e

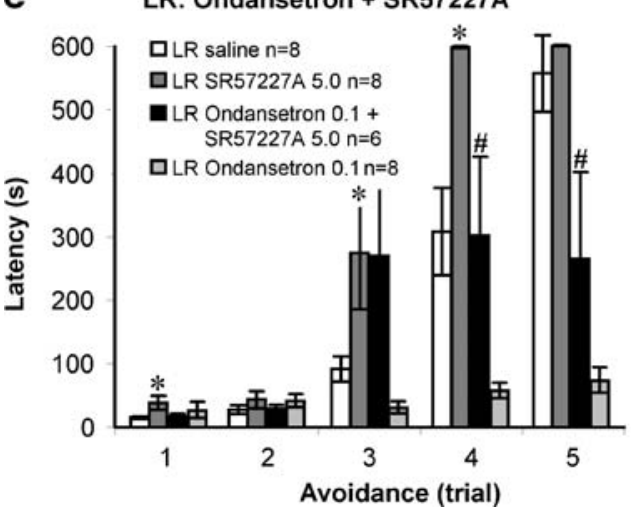

b HR: SR57227A

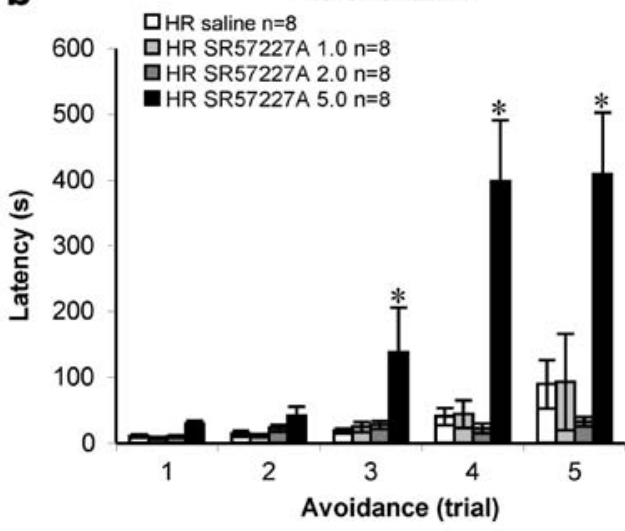

d

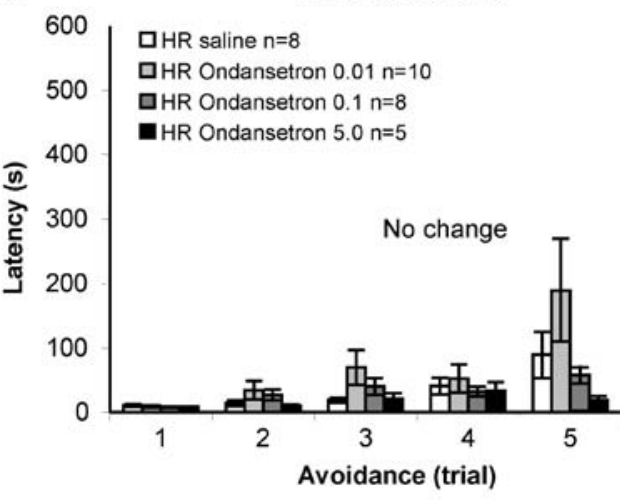

f

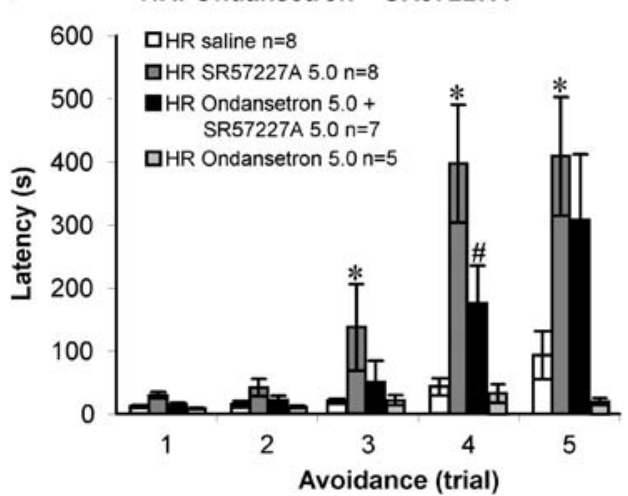

5-HT3 drugs Figure 1 shows that the 5-HT3 agonist SR57227A differentially affected the duration of avoidance behaviour in LR and HR rats (ANCOVA: type $\times$ treatment effect, $\left.F_{(3,341)}=13.01, p<0.001\right)$. SR57227A increased avoidance behaviour in both LR (Fig. 1a-ANCOVA: treatment effect, $\left.F_{(3,172)}=11.56, p<0.001\right)$ and $\mathrm{HR}$ rats (Fig. 1b-ANCOVA: treatment effect, $F_{(3,168)}=19.80$, $p<0.001)$. In LR rats, all doses of SR57227A increased avoidance behaviour (Fig. $1 \mathrm{a}-0$ vs $1 \mathrm{mg} / \mathrm{kg}, p=0.010 ; 0$ vs $2 \mathrm{mg} / \mathrm{kg}, p<0.001 ; 0$ vs $3 \mathrm{mg} / \mathrm{kg}, p=0.005)$, whereas only the highest dose of this drug increased avoidance behaviour in $\mathrm{HR}$ rats (Fig. $1 \mathrm{~b}-0$ vs $1 \mathrm{mg} / \mathrm{kg}$, n.s.; 0 vs $2 \mathrm{mg} / \mathrm{kg}$, n.s.; 0 vs $3 \mathrm{mg} / \mathrm{kg}, p<0.001)$. In addition, SR57227A increased the duration of avoidance already at trials $1-4$ in LR rats (Fig. 1a), but only at trials $3-5$ in HR rats (Fig. 1b). Figure 1 also illustrates that the 5-HT3 antagonist ondansetron had differential effects in LR and HR rats (ANCOVA: type $\times$ treatment effect, $F_{(2,286)}=6.82$, $p=0.001)$. Ondansetron decreased the duration of avoidance behaviour in LR rats (Fig. 1c-ANCOVA: treatment effect, $F_{(2,132)}=8.87, p<0.001 ; 0$ vs $0.01 \mathrm{mg} / \mathrm{kg}, p=0.026 ; 0$ vs $0.1 \mathrm{mg} / \mathrm{kg}, p<0.001$ ), but not in HR rats (Fig. 1d-ANCOVA: treatment effect, n.s.; 0 vs $0.01 \mathrm{mg} / \mathrm{kg}$, n.s.; 0 vs $0.1 \mathrm{mg} / \mathrm{kg}$, n.s.; and 0 vs $5.0 \mathrm{mg} / \mathrm{kg}$, n.s.). Ondansetron attenuated the SR57227A-induced increase of avoidance in both LR rats (Fig. 1e-SR57227A vs ondansetron + SR57227A: ANCOVA, treatment effect, $\left.F_{(1,71)}=6.76, p=0.011\right)$ and HR rats (Fig. 1f-SR57227A vs ondansetron + SR57227A: 
Fig. 2 Effects of the 5-HT2C agonists DOI $(\mathbf{a}, \mathbf{b})$ and $\mathrm{mCPP}$ (c, d), the 5-HT2A/C antagonist ritanserin $(\mathbf{e}, \mathbf{f})$ and the combination of $\mathrm{mCPP}$ and ritanserin $(\mathbf{g}, \mathbf{h})$ on the duration of avoidance of the open arms in LR (left) and HR (right) rats. Asterisks Significant change vs saline. Number signs Significant increase/decrease vs $\mathrm{mCPP}$
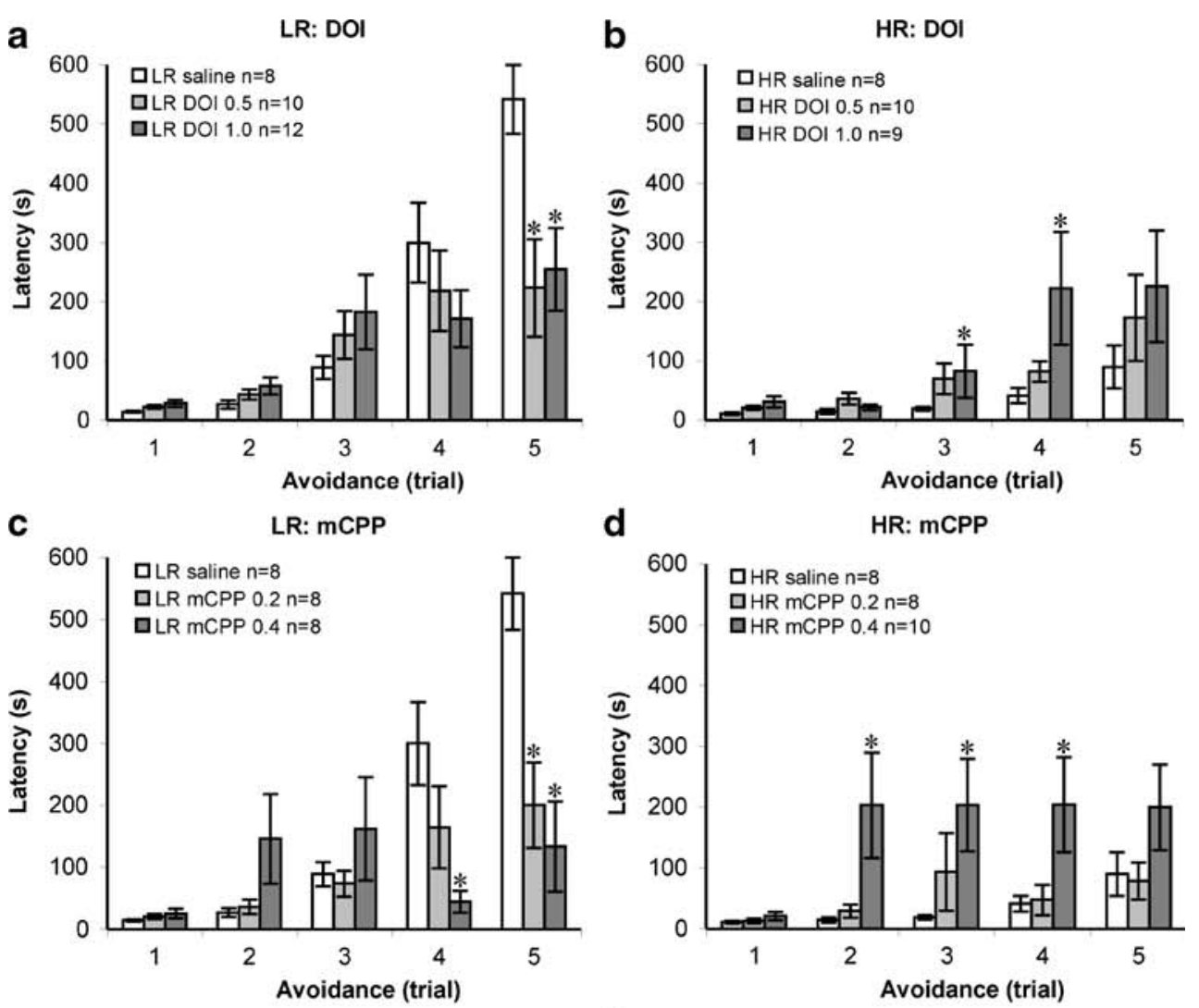

d

HR: mCPP
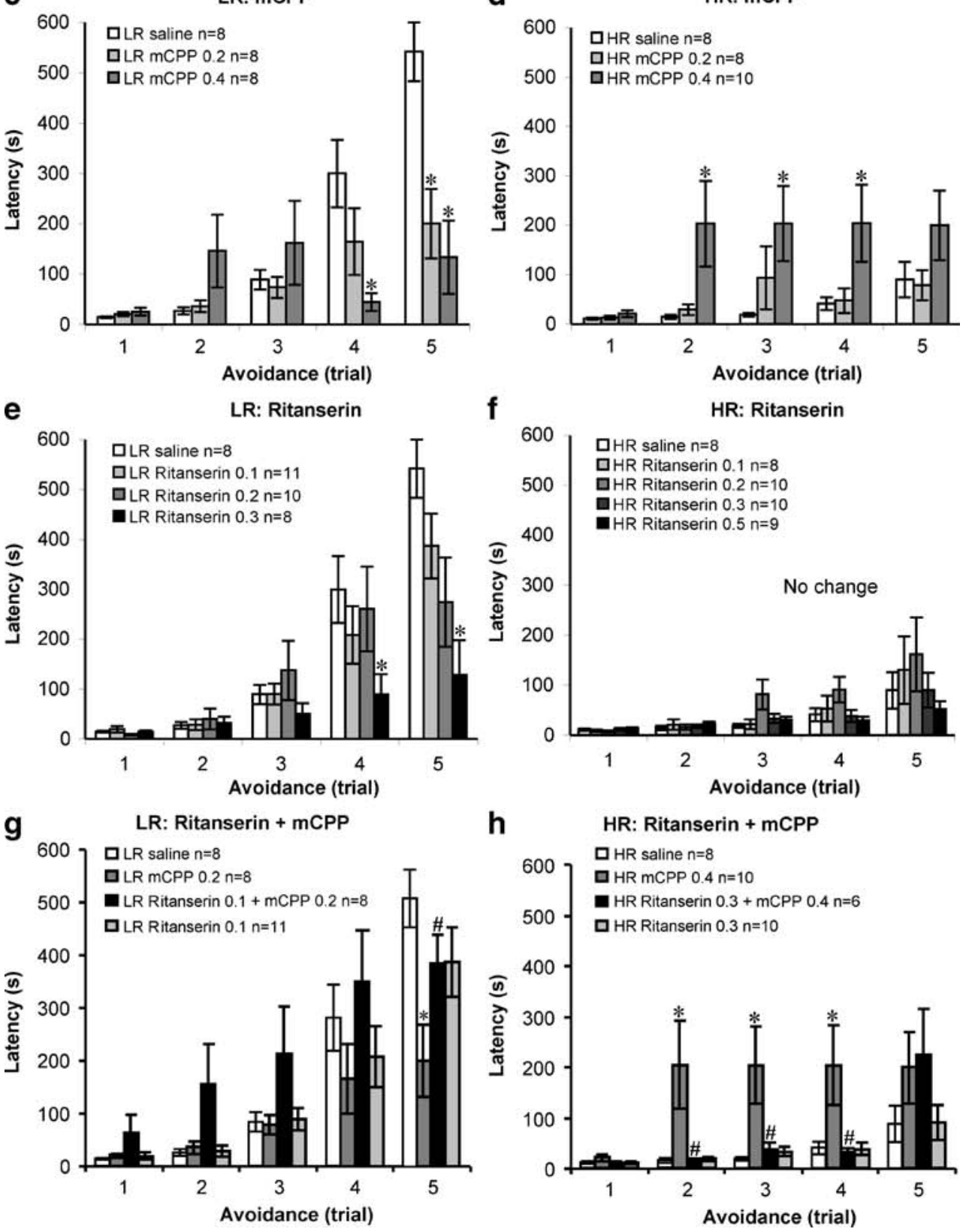
Fig. 3 Effects of the 5-HT1A agonist 8-OH-DPAT $(\mathbf{a}, \mathbf{b})$, the 5-HT1A antagonist

WAY100635 (c, d) and the combination of both $(\mathbf{e}, \mathbf{f})$ on the duration of avoidance of the open arms in LR (left) and HR (right) rats. Asterisks Significant change vs saline. Number signs Significant decrease vs WAY100635
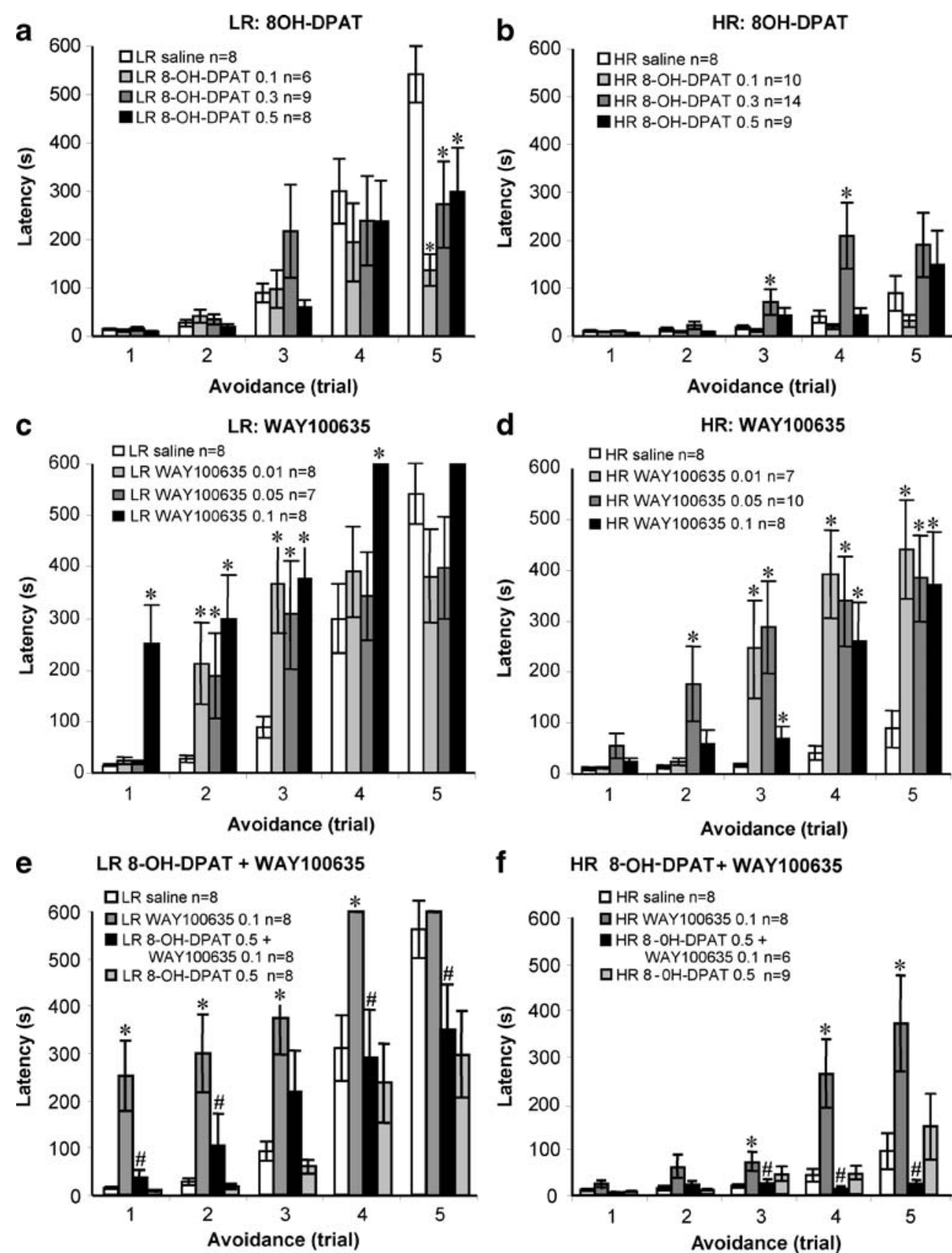

ANCOVA, treatment effect, $F_{(1,75)}=6.05, p=0.016$ ). Finally, the duration of avoidance induced by the combination of ondansetron and SR57227A differed from the duration of avoidance induced by ondansetron alone in LR rats (Fig. 1eondansetron + SR57227A vs ondansetron: ANCOVA, treatment effect, $\left.F_{(1,65)}=13.87, p<0.001\right)$ and in HR rats (Fig. 1f-ondansetron + SR57227A vs ondansetron: ANCOVA, treatment effect, $\left.F_{(1,62)}=6.38, p=0.014\right)$.

5-HT2 drugs Figure 2 illustrates that the 5-HT2A/C agonist DOI differentially affected the duration of avoidance behaviour in LR and HR rats (ANCOVA: type $\times$ treatment effect, $\left.F_{(2,294)}=7.69, p=0.001\right)$. DOI decreased avoidance behaviour in LR rats (Fig. 2a-ANCOVA: treatment effect, $F_{(2,156)}=3.30, p=0.040 ; 0$ vs $0.5 \mathrm{mg} / \mathrm{kg}$, $p=0.039 ; 0$ vs $1 \mathrm{mg} / \mathrm{kg}, p=0.041)$, but increased avoidance behaviour in HR rats (Fig. 2b-ANCOVA: treatment effect, $F_{(2,137)}=5.83, p=0.004 ; 0$ vs $0.5 \mathrm{mg} / \mathrm{kg}$, n.s.; 0 vs $1 \mathrm{mg} / \mathrm{kg}, p=0.001)$. Since a decrease in the duration of avoidance behaviour following a 5-HT2 agonist was unexpected (see "Introduction"), the effects of an additional 5-HT2 agonist were tested. The effects of the 5HT2C agonist mCPP were similar to the effects of DOI. Figure 2 shows that $\mathrm{mCPP}$ had differential effects in LR and HR rats (ANCOVA: type $\times$ treatment effect, $F_{(2,265)}=$ 12.10, $p<0.001)$. Similar to DOI, mCPP decreased 
Fig. 4 Effects of the 5-HT reuptake inhibitor/5-HT releaser $d$-fenfluramine (a, b) and the combination of the 5-HT3 antagonist ondansetron and $d$-fenfluramine $(\mathbf{c}, \mathbf{d})$ on the duration of avoidance of the open arms in LR (left) and HR (right) rats. Asterisks Significant change vs saline. Number signs Significant decrease vs $d$-fenfluramine a

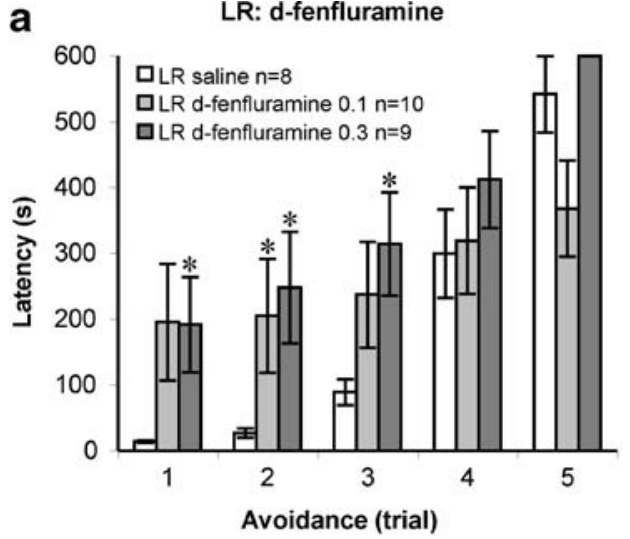

C

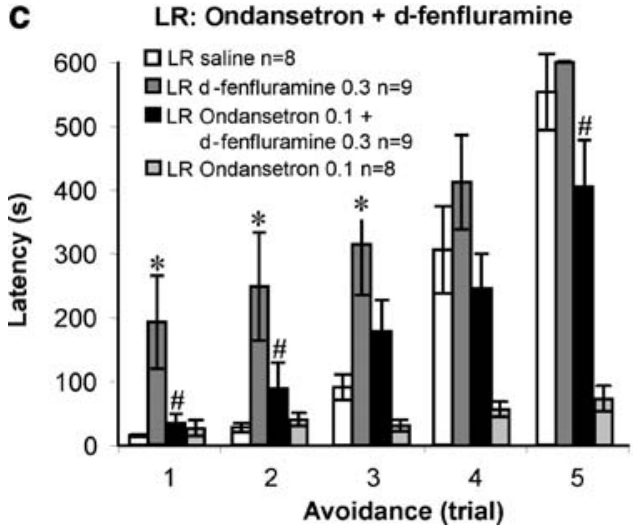

b

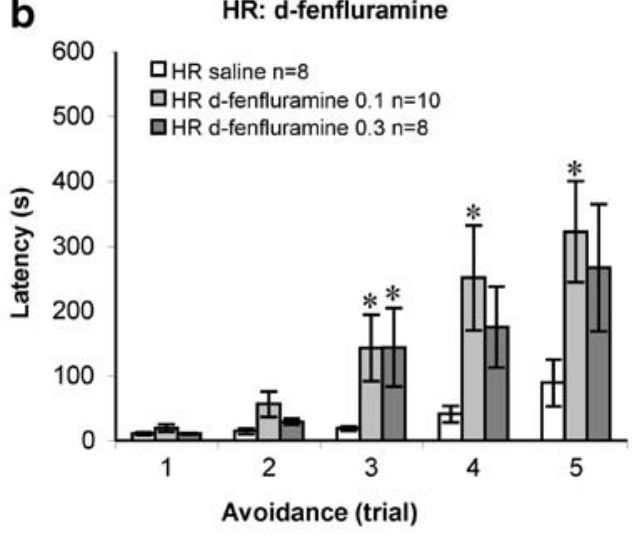

d HR: Ondansetron + d-fenfluramine

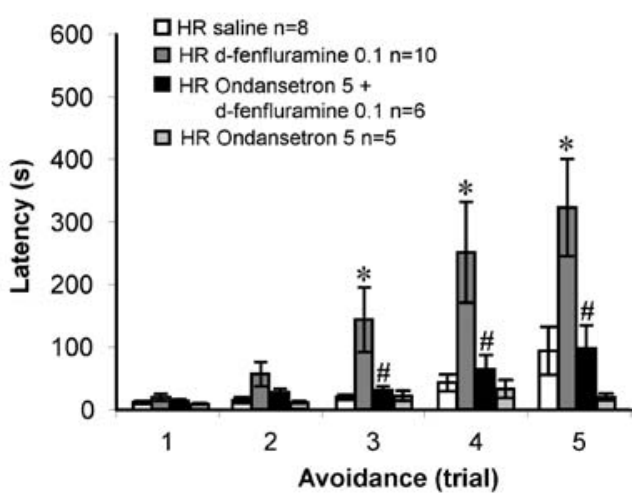

avoidance in LR (Fig. 2c-ANCOVA: treatment effect, $F_{(2,131)}=3.72, p=0.027 ; 0$ vs $0.2 \mathrm{mg} / \mathrm{kg}, p=0.026 ; 0$ vs $0.4 \mathrm{mg} / \mathrm{kg}, p=0.040$ ), whereas $\mathrm{mCPP}$ increased avoidance in HR (Fig. 2d-ANCOVA: treatment effect, $F_{(2,133)}=13.12$, $p<0.001 ; 0$ vs $0.2 \mathrm{mg} / \mathrm{kg}$, n.s.; 0 vs $0.4 \mathrm{mg} / \mathrm{kg}, p<0.001$ ). Figure 2 also illustrates that the $5-\mathrm{HT} 2 \mathrm{~A} / \mathrm{C}$ antagonist ritanserin had differential effects in LR and HR rats (ANCOVA: type $\times$ treatment effect, $F_{(3,428)}=3.59, p=0.014$ ). Ritanserin decreased the duration of avoidance behaviour in LR (Fig. 2e-ANCOVA: treatment effect, $F_{(3,192)}=4.68$, $p=0.004 ; 0$ vs $0.1 \mathrm{mg} / \mathrm{kg}$, n.s.; 0 vs $0.2 \mathrm{mg} / \mathrm{kg}$, n.s.; 0 vs $0.3 \mathrm{mg} / \mathrm{kg}, p<0.001$ ), but not in HR (Fig. $2 \mathrm{f}-$ ANCOVA: treatment effect, n.s.; 0 vs $0.1 \mathrm{mg} / \mathrm{kg}$, n.s.; 0 vs $0.2 \mathrm{mg} / \mathrm{kg}$, n.s.; 0 vs $0.3 \mathrm{mg} / \mathrm{kg}$, n.s.; 0 vs $0.5 \mathrm{mg} / \mathrm{kg}$, n.s.). Both the mCPP-induced decrease of avoidance behaviour in LR rats and the mCPP-induced increase of avoidance behaviour in HR rats were attenuated by ritanserin (LR rats (Fig. 2g) $\mathrm{mCPP}$ vs mCPP + ritanserin: ANCOVA, treatment effect, $F_{(1,79)}=11.72, p=0.001$; HR rats (Fig. 2h) -mCPP vs mCPP + ritanserin: ANCOVA, treatment effect, $F_{(1,73)}=$ $4.87, p=0.030$ ). Finally, the duration of avoidance induced by the combination of ritanserin and $\mathrm{mCPP}$ differed from the duration of avoidance induced by ritanserin alone in LR (Fig. $2 \mathrm{~g}-\mathrm{mCPP}+$ ritanserin vs ritanserin: ANCOVA, treatment effect, $\left.F_{(1,92)}=5.68, p=0.019\right)$, but not in HR rats (Fig. $2 \mathrm{~h}-\mathrm{mCPP}+$ ritanserin vs ritanserin: ANCOVA, treatment effect, n.s.).
5-HT1 drugs The 5-HT1A agonist 8-OH-DPAT had differential effects on the duration of avoidance behaviour in LR and HR rats (ANCOVA: type $\times$ treatment effect, $F_{(3,385)}=$ $4.19, p=0.006$ ). Figure 3 illustrates that 8-OH-DPAT decreased avoidance behaviour in LR rats (Fig. 3a-ANCOVA: treatment effect, $F_{(3,163)}=2.88, p=0.038 ; 0$ vs $0.1 \mathrm{mg} / \mathrm{kg}$, $p=0.011 ; 0$ vs $0.3 \mathrm{mg} / \mathrm{kg}, p=0.023 ; 0$ vs $0.5 \mathrm{mg} / \mathrm{kg}$, $p=0.060$ ), whereas it increased avoidance behaviour in HR rats (Fig. 3b-ANCOVA: treatment effect, $F_{(3,221)}=8.07$, $p<0.001 ; 0$ vs $0.1 \mathrm{mg} / \mathrm{kg}$, n.s.; 0 vs $0.3 \mathrm{mg} / \mathrm{kg}, p<0.001$; and 0 vs $0.5 \mathrm{mg} / \mathrm{kg}$, n.s.). Figure 3 also shows that the $5-$ HT1A antagonist WAY100635 had differential effects in LR and HR rats (ANCOVA: type $\times$ treatment effect, $F_{(3,332)}=7.89$, $p<0.001)$. WAY100635 increased avoidance behaviour in both LR rats (Fig. 3c-ANCOVA: treatment effect, $F_{(3,166)}=$ $12.49, p<0.001 ; 0$ vs $0.01 \mathrm{mg} / \mathrm{kg}, p=0.011 ; 0$ vs $0.05 \mathrm{mg} / \mathrm{kg}$, $p=0.052 ; 0$ vs $0.1 \mathrm{mg} / \mathrm{kg}, p<0.001)$ and HR rats (Fig. $3 \mathrm{~d}-$ ANCOVA: treatment effect, $F_{(3,165)}=11.76, p<0.001 ; 0$ vs $0.01 \mathrm{mg} / \mathrm{kg}, p<0.001 ; 0$ vs $0.05 \mathrm{mg} / \mathrm{kg}, p<0.001 ; 0$ vs $0.1 \mathrm{mg} / \mathrm{kg}, p=0.001)$. However, WAY100635 increased the duration of avoidance already at trials $1-4$ in LR rats (Fig. 3c), but only at trials $2-5$ in HR rats (Fig. 3d). The WAY100635-induced increase of avoidance was counteracted by 8-OH-DPAT in both LR rats (Fig. 3e-WAY100635 vs 8-OH-DPAT + WAY100635: ANCOVA, treatment effect, $F_{(1,79)}=33.02, p<0.001$ ) and HR rats (Fig. $3 \mathrm{f}-$ WAY100635 vs 8-OH-DPAT + WAY100635: ANCOVA, 
treatment effect, $\left.F_{(1,67)}=15.52, p<0.001\right)$. Finally, the duration of avoidance following the combination of 8 OH-DPAT and WAY100635 was significantly different from the duration of avoidance following 8-OH-DPAT alone in LR rats (Fig. 3e-8-OH-DPAT + WAY 100635 vs 8-OH-DPAT: ANCOVA, treatment effect, $F_{(1,83)}=4.68, p=$ 0.034 ) and in HR rats (Fig. $3 \mathrm{f}-8-\mathrm{OH}-\mathrm{DPAT}+$ WAY 100635 vs 8-OH-DPAT: ANCOVA, treatment effect, $\left.F_{(1,77)}=4.02, p=0.049\right)$.

$d$-Fenfluramine Figure 4 illustrates that the 5-HT releaser/ reuptake blocker $d$-fenfluramine differentially affected the duration of avoidance behaviour in LR and HR rats (ANCOVA: type $\times$ treatment effect, $F_{(2,285)}=3.75, p=0.026$ ). Although $d$-fenfluramine increased the duration of avoidance behaviour in both LR rats (Fig. $4 \mathrm{a}$-ANCOVA: treatment effect, $F_{(2,150)}=7.50, p=0.001 ; 0$ vs $0.1 \mathrm{mg} / \mathrm{kg}, p=0.034 ; 0$ vs $0.3 \mathrm{mg} / \mathrm{kg}, p<0.001$ ) and HR rats (Fig. 4b-ANCOVA: treatment effect, $F_{(2,134)}=8.48, p<0.001 ; 0$ vs $0.1 \mathrm{mg} / \mathrm{kg}$, $p<0.001 ; 0$ vs $0.3 \mathrm{mg} / \mathrm{kg}, p=0.006$ ), post hoc analysis revealed that, similar to SR57227A, $d$-fenfluramine already increased avoidance behaviour at trials $1-3$ in LR (Fig. 4a), but only at trials 3-5 in HR rats (Fig. 4b). Because our data suggest that the action of $d$-fenfluramine may be due to stimulation of 5 HT3 receptors (see "Discussion"), we also investigated the effects of the 5-HT3 antagonist ondansetron on the $d$ fenfluramine-induced changes of avoidance. Ondansetron was found to attenuate the $d$-fenfluramine-induced increase of avoidance in both LR rats (Fig. $4 \mathrm{c}-d$-fenfluramine vs ondansetron $+d$-fenfluramine: ANCOVA, treatment effect, $F_{(1,95)}=4.85, p=0.030$ ) and HR rats (Fig. $4 d-d$-fenfluramine vs ondansetron $+d$-fenfluramine: ANCOVA, treatment effect, $\left.F_{(1,77)}=11.29, p=0.001\right)$. The duration of avoidance induced by the combination of ondansetron and $d$-fenfluramine was different from the duration of avoidance induced by ondansetron alone in LR rats (Fig. $4 \mathrm{c}$ - ondansetron $+d$-fenfluramine vs $d$-fenfluramine: ANCOVA, $\left.F_{(1,78)}=28.66, p<0.001\right)$ and in HR rats (Fig. $4 \mathrm{~d}$-ondansetron $+d$-fenfluramine vs $d$-fenfluramine: ANCOVA, treatment effect, $F_{(1,56)}=7.46$, $p=0.008$ ).

5-HT1 and 5-HT2/5-HT3 drugs In order to investigate whether the behavioural effects of WAY100635, which is suggested to act at presynaptic 5-HT1A receptors (see "Discussion"), could be inhibited by an antagonist that is suggested to act at postsynaptic 5-HT2 or 5-HT3 receptors (see "Discussion"), rats were treated with a cocktail of WAY100635 and ritanserin or WAY100635 and ondansetron. The 5-HT2A/C antagonist ritanserin did not inhibit the WAY100635-induced increase of avoidance in either LR rats (Fig. 5a-WAY100635 vs ritanserin + WAY100635: ANCOVA, treatment effect, n.s.) or HR rats (Fig. 5bWAY100635 vs ritanserin + WAY100635: ANCOVA, treatment effect, n.s.). The duration of avoidance induced by the combination of ritanserin and WAY100635 differed from the duration of avoidance induced by ritanserin alone in
Fig. 5 Effects of the 5-HT2A/C antagonist ritanserin $(\mathbf{a}, \mathbf{b})$ and the 5-HT3 antagonist ondansetron $(\mathbf{c}, \mathbf{d})$ on the WAY100635-induced increase of the duration avoidance behaviour in LR (left) and HR (right) rats. Asterisks Significant change vs saline. Number signs Significant decrease vs WAY 100635
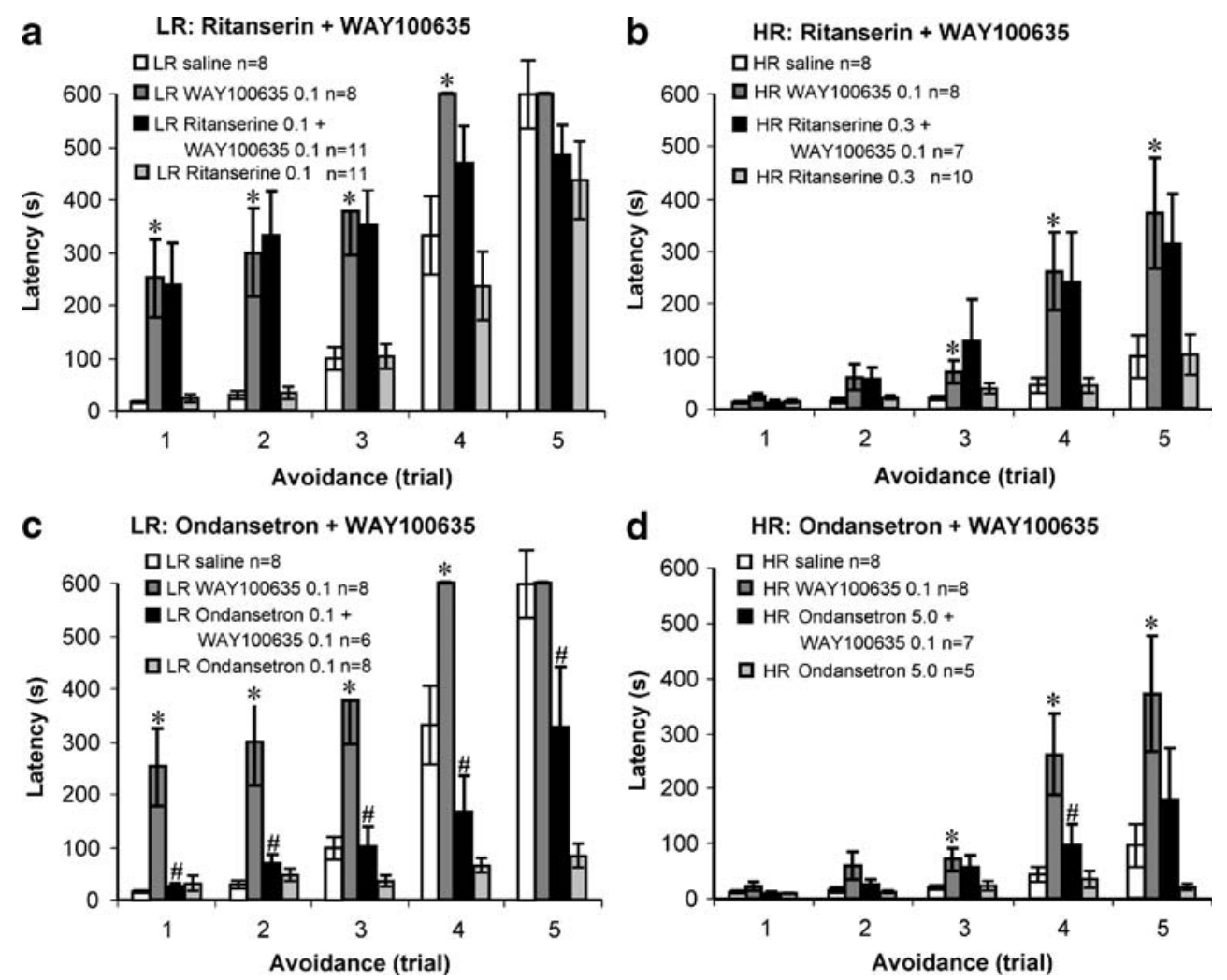
LR (Fig. 5a-ritanserin + WAY100635 vs ritanserin: ANCOVA, treatment effect, $\left.F_{(1,107)}=37.82, p<0.001\right)$ and in HR (Fig. 5b-ritanserin + WAY100635 vs ritanserin: ANCOVA, treatment effect, $\left.F_{(1,83)}=15.42, p<0.001\right)$. The 5-HT3 antagonist ondansetron inhibited the WAY100635induced increase of avoidance in both LR rats (Fig. 5cWAY100635 vs ondansetron + WAY100635: ANCOVA, treatment effect, $\left.F_{(1,73)}=40.48, p<0.001\right)$ and HR rats (Fig. 5d-WAY100635 vs ondansetron + WAY100635: ANCOVA, treatment effect, $\left.F_{(1,74)}=6.51, p=0.013\right)$. The duration of avoidance induced by the combination of ondansetron and WAY100635 differed from the duration of avoidance induced by ondansetron alone in LR rats (Fig. $5 \mathrm{c}-$ ondansetron + WAY100635 vs ondansetron: ANCOVA, treatment effect, $\left.F_{(1,63)}=13.11, p=0.001\right)$ and in HR rats (Fig. 5d-ondansetron + WAY100635 vs ondansetron: ANCOVA, treatment effect, $F_{(1,61)}=6.70, p=0.012$ ).

\section{Discussion}

Summary of the results

The aim of the present study was to assess individual differences in the sensitivity to serotonergic drugs between rats that were characterised as HR and LR to novelty. The 5-HT3 agonist SR57227A increased the duration of avoidance behaviour in both types of rat (Fig. 1a/b). However, higher doses of SR57227A were required to alter the duration of avoidance behaviour in HR than in LR rats (Fig. 1a/b). The 5-HT3 antagonist ondansetron decreased avoidance behaviour in LR rats, but had no effects in HR rats (Fig. 1c/d). Remarkably, the 5-HT2 agonists mCPP and DOI decreased the duration of avoidance behaviour in LR rats, but increased the duration of this behaviour in HR rats (Fig. 2a-d). The 5-HT2 antagonist ritanserin decreased avoidance behaviour in LR rats, but had no effects in HR rats (Fig. 2e/f). The 5-HT1A agonist 8-OH-DPAT decreased the duration of avoidance behaviour in LR rats, but increased the duration of this behaviour in HR rats (Fig. 3a/b). Both the 5-HT1A antagonist WAY100635 (Fig. 3c/d) and the serotonin releaser/reuptake inhibitor $d$ fenfluramine (Fig. 4a/b) increased avoidance behaviour in both types of rat. However, the onset of the effects of WAY 100635 (Fig. 3c/d) and $d$-fenfluramine (Fig. 4a/b) was faster in LR than in HR rats. The same held true for the onset of the effects of SR57227A (Fig. 1a/b). Finally, the duration of avoidance behaviour was larger in control LR rats compared to control HR rats (Figs. 1, 2, 3 and 4). These data demonstrate that LR and HR rats differ in their sensitivity to all serotonergic drugs that were tested. Apart from the direction of the effects of DOI and $\mathrm{mCPP}$ in LR rats, the direction of the effects of the remaining serotonergic agents nicely fit in with the available literature (for reference, see "Introduction").

Below, a model will be presented to explain our results. The model is based on the original finding by Graeff et al. that the duration of avoidance of the open arms becomes larger as synaptic serotonin levels increase (Graeff et al. 1996a, b, 1998; Mora et al. 1997; Viana et al. 1997). The finding that $d$-fenfluramine, a drug that is known to increase the levels of serotonin in the synapse (Consolo et al. 1979; Gundlah et al. 1997), increases the duration of avoidance behaviour in both LR (Fig. 4a) and HR (Fig. 4b) rats is nicely in line with the previously reported findings by Graeff et al.

\section{Model explaining the results}

5-HT3 drugs The effects of SR57227A in HR rats were inhibited by a behaviourally silent dose $(5.0 \mathrm{mg} / \mathrm{kg})$ of the 5-HT3 antagonist ondansetron (Fig. 1f), suggesting that the SR57227A-induced changes in the duration of avoidance behaviour are mediated by 5 -HT3 receptors. The fact that SR57227A resulted in an increase of avoidance (Fig. 1a/b) indicates that this agonist acts at postsynaptic 5-HT3 receptors. It has recently been shown that LR and HR rats do not differ in their 5-HT3 receptor expression (Ballaz et al. 2007a). Combining this previous finding with the present finding that higher doses of SR57227A were required to alter the duration of avoidance behaviour in HR than in LR (Fig. 1a/b) results in the notion that LR rats are characterised by postsynaptic 5-HT3 receptors that are more sensitive than those of HR rats (Fig. 6). This is supported by the finding that all doses of the 5-HT3 antagonist ondansetron decreased the duration of avoidance behaviour in LR rats (Fig. 1c), whereas none of the tested doses of this drug decreased the duration of avoidance behaviour in HR rats (Fig. 1d).

5-HT2 drugs In HR rats, the effects of the 5-HT2C agonist $\mathrm{mCPP}$ were blocked by a behaviourally silent dose $(0.3 \mathrm{mg} / \mathrm{kg})$ of the 5-HT2A/C antagonist ritanserin (Fig. 2h). These data suggest that the mCPP-induced changes in the duration of avoidance behaviour are mediated by 5 -HT2C receptors. The results of the 5-HT2A/C agonist DOI were similar to the results of $\mathrm{mCPP}$, indicating that the effects of DOI were also mediated by $5-\mathrm{HT} 2 \mathrm{C}$ receptors. The fact that both $\mathrm{mCPP}$ and DOI resulted in an increase of avoidance in HR (Fig. 2b/d), but not in LR (Fig. 2a/c) indicates that the serotonergic projection regions of $\mathrm{HR}$ rats are marked by more or more sensitive postsynaptic 5-HT2C receptors than the serotonergic projection regions of LR rats (Fig. 6). The finding that the 5HT2C agonists mCPP and DOI decreased the duration of avoidance behaviour in LR (Fig. 2a/c) suggest that these drugs 
reduced synaptic serotonin levels in these rats. This decrease of serotonergic activity cannot simply be explained by an action at presynaptic 5-HT2 autoreceptors because 5-HT2 receptors have found to be located postsynaptically only (Barnes and Sharp 1999). Recent studies, however, have revealed that the synaptic serotonergic activity is reduced after stimulation of postsynaptic 5-HT2 receptors that are located on inhibitory GABAergic interneurons in the dorsal raphe (Liu et al. 2000; Boothman et al. 2003; Serrats et al. 2005; Boothman and Sharp 2005). These GABAergic neurons are supposed to be part of a feedback loop. We, therefore, hypothesise that LR rats exhibit more or more sensitive 5HT2C receptors that are located on this feedback loop than HR rats (Fig. 6). Ritanserin decreased the duration of avoidance behaviour in LR (Fig. 2e), but not in HR (Fig. 2f) rats. Given the lack of effects of $\mathrm{mCPP}$ at the postsynaptic 5-HT2C receptors of the serotonergic projection regions of LR rats (see above), these data can only be explained by an action of ritanserin in the serotonergic projection regions containing postsynaptic 5-HT2A receptors (Fig. 6). Our data indicate that LR rats are marked by more or more sensitive postsynaptic 5-HT2A receptors that belong to this feedforward loop than HR rats (Fig. 6). The fact that a behaviourally silent dose $(0.1 \mathrm{mg} / \mathrm{kg})$ of the 5 -HT2A agent ritanserin inhibited the effects of the 5-HT2C agent mCPP in LR (Fig. 2g) strongly suggests that the postsynaptic 5-HT2A receptors that belong to the feedforward loop of these rats are located on the same pathway as the 5-HT2C receptors that belong to the feedback loop of these rats (Fig. 6).

5-HT1 drugs The effects of WAY100635 during trials 1 and 2 in LR rats were inhibited by the 5-HT1A agonist 8OH-DPAT (Fig. 3e), which in itself was not effective during these trials (Fig. 3a), suggesting that the WAY100635induced changes in the duration of avoidance behaviour are mediated by 5-HT1A receptors. WAY100635 has been found to increase avoidance behaviour only when it acts presynaptically (Dos Santos et al. 2005; Dos-Santos et al. 2008). The finding that WAY100635 increases avoidance in LR (Fig. 3c) and in HR (Fig. 3d) indicates that inhibitory presynaptic 5-HT1A receptors are present in both types of rat (Fig. 6). The 5-HT1A agonist 8-OH-DPAT increased the duration of the avoidance behaviour in HR (Fig. 3b), but not in LR (Fig. 3a) rats. 8-OH-DPAT has been reported to result in an increase of avoidance behaviour only when its acts postsynaptically (Dos-Santos et al. 2008; Viana et al. 2008). Therefore, our data suggest the presence of more or more sensitive postsynaptic 5-HT1A receptors in HR than in LR rats (Fig. 6). The fact that a behaviourally silent dose $(0.5 \mathrm{mg} / \mathrm{kg})$ of the postsynaptic acting 5-HT1A agent 8OH-DPAT inhibited the effects of the presynaptic acting 5HT1A agent WAY100635 in HR (Fig. 3f) illustrates that the neurons that contain pre- and postsynaptic 5-HT1A receptors in these rats are located on the same pathway (Fig. 6). A presynaptic action of 8-OH-DPAT has repeatedly been reported to result in a decrease of avoidance (Sena et al. 2003; Dos Santos et al. 2005; Vicente et al. 2008). The finding that 8-OH-DPAT decreased the duration of avoidance in LR (Fig. 3a) can be explained by the already discussed presence of presynaptic 5-HT1A autoreceptors in these rats (Fig. 6).

Combination of 5-HT1, 5-HT2 and 5-HT3 drugs The finding that the 5-HT2A/C antagonist ritanserin did not inhibit the WAY100635-induced increase in the duration of avoidance behaviour in either LR (Fig. 5a) or HR (Fig. 5b) rats suggests that the pathway that contains presynaptic 5-HT1A receptors does not contain postsynaptic 5-HT2A or 5-HT2C receptors (Fig. 6). The avoidance-increasing effects of WAY 100635 were inhibited by the dose of $0.1 \mathrm{mg} / \mathrm{kg}$ of the $5-\mathrm{HT} 3$ antagonist ondansetron in both LR (Fig. 5c) and HR (Fig. 5d) rats. This dose of ondansetron itself did not change avoidance behaviour during trials $1-2$ in LR rats (Fig. 1c) and during trials $1-5$ in HR rats (Fig. 1d). Our data, therefore, indicate that the presynaptic 5-HT1A receptors and the postsynaptic 5HT3 receptors belong to the same pathway (Fig. 6).

$d$-Fenfluramine The effects of $d$-fenfluramine appeared to be very similar to the effects of the 5-HT3 agonist SR57227A. More specifically, both drugs increased the duration of avoidance behaviour in $\mathrm{HR}$ and in LR rats (Figs. 1 and 4), whereas the 5-HT2C agonists (DOI and mCPP) and the 5-HT1A agonist (8-OH-DPAT) increased the duration of avoidance behaviour in HR rats, but decreased the duration of avoidance behaviour in LR rats (Figs. 2 and 3). Similar to the onset of the effects of SR57227A, the onset of the effects of $d$-fenfluramine was faster in LR (Fig. 1a vs Fig. 4a-trials 1-3) than in HR (Fig. 1b vs Fig. 4b-trials 3-5) rats. This striking similarity between the effects of the serotonin reuptake inhibitor/ serotonin releaser $d$-fenfluramine and SR57227A suggests that the action of $d$-fenfluramine is mediated mainly via postsynaptic 5-HT3 receptors and not (or less) via postsynaptic 5-HT1A or 5-HT2A/C receptors (see also Consolo et al. 1994). This notion is supported by our finding that the avoidance-increasing effects of $d$-fenfluramine during trials $1-2$ in LR rats and during trials 3-5 in HR rats were strongly inhibited by the dose of $0.1 \mathrm{mg} / \mathrm{kg}$ of the 5-HT3 antagonist ondansetron (Fig. 4c/d), which in itself was not effective at these trials (Fig. 1c/d).

Saline Injection stress and exposure to a novel behavioural setup have both been found to increase synaptic serotonin levels (Adell et al. 1997; Thomas et al. 2000). The finding that the duration of avoidance of the open arms increased more strongly in naive or saline-treated LR than in naive or saline- 

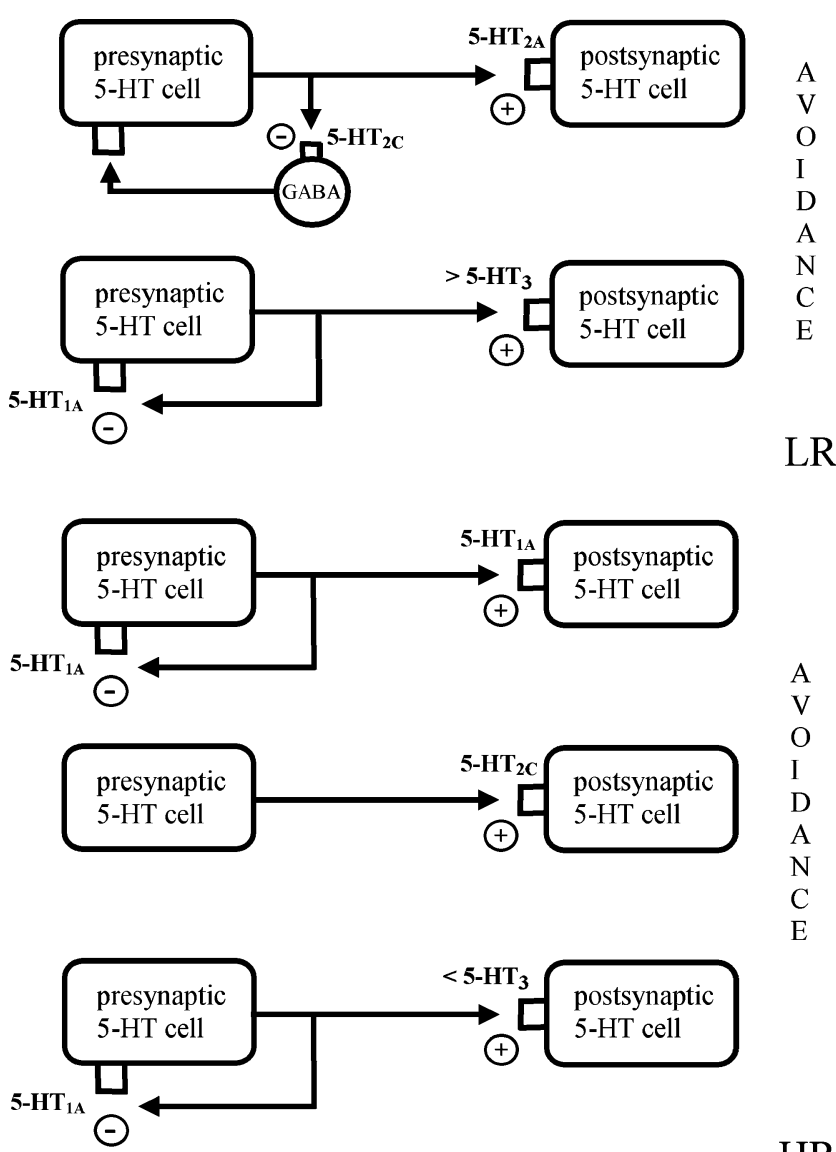

HR

Fig. 6 Putative serotonergic system of the brain of LR (upper panel) and HR (lower panel) rats. $\oplus$ receptors that stimulate avoidance behaviour, $\odot$ receptors that reduce avoidance behaviour. $>$ relatively sensitive receptors, $<$ relatively insensitive receptors

treated HR (Figs. 1, 2, 3 and 4) indicates that serotonin levels increase more strongly in challenged LR rats than in challenged HR rats. This behavioural finding nicely fits in with the neurochemical finding of Piazza et al. (1991b) that the brain levels of serotonin are relatively large in LR compared to HR rats. Although analysis over all trials clearly revealed individual differences in avoidance behaviour in saline-treated LR and HR rats, no individual differences were found between these two types of rat during the first trial of the elevated T-maze. This finding confirms the previously reported finding that a single exposure to the elevated plusmaze does not result in behavioural differences between LR and HR rats (Thiel et al. 1999; Ballaz et al. 2007b), whereas repeated exposure does (Ballaz et al. 2007b).

Personality traits explaining the results

Effects are not due to individual differences in anxiety The elevated T-maze is generally used to measure anxiety related behaviour (Graeff et al. 1996a, b 1998). Rats bred for high anxiety behaviour are typically marked by a larger challenged-induced increase of corticosterone and ACTH compared to rats bred for low anxiety behaviour (Liebsch et al. 1998; Landgraf et al. 1999). The fact that challenged LR rats have been found to be marked by smaller levels of corticosterone and ACTH than challenged HR rats (Piazza et al. 1991a; Rots et al. 1995, 1996; Kabbaj et al. 2000, 2007) strongly indicates that the relatively large challenge-induced increase in the duration of avoidance behaviour in control LR rats (Figs. 1, 2, 3 and 4) is not due to a relatively large level of anxiety in these rats. Accordingly, alternative traits may have caused the serotonin-induced individual differences in the duration of avoidance behaviour in our rats.

Effects may be due to individual differences in habituation to a new environment It has previously been hypothesised that the behavioural response during the first trial of a particular test may be of a different nature than the behavioural response during the remaining trials of this test (File et al. 1993; Ballaz et al. 2007b). In addition to SR57227A and $d$-fenfluramine, WAY100635 was found to result in a larger increase of avoidance behaviour during trial 1 in LR than in HR rats (Fig. 3). Remarkably, the remaining drugs (saline, ondansetron, DOI, mCPP, ritanserin and 8-OH-DPAT) did not result in individual differences in avoidance behaviour during the first trial. The fact that the presynaptic acting agent WAY100635 increased avoidance behaviour in the same trial as the postsynaptic acting agent SR57227A fits in with our above-mentioned notion that the presynaptic 5-HT1A receptors belong to the same pathway as postsynaptic 5-HT3 receptors (Fig. 6). On the basis of these considerations, it is suggested that the pathway containing postsynaptic 5-HT3 receptors (Fig. 6) is important in mediating the immediate response to a novel environment, whereas the pathways containing postsynaptic 5HT1A and 5-HT2 receptors (Fig. 6) may be more important in mediating the behavioural response after reexposure to this environment. Based on the criteria that were used to select HR and LR rats (see "Methods"), we hypothesise that the observed individual differences in the time to approach the open arms of the T-maze are due to individual differences in exploration of a novel environment (possible mediated by postsynaptic 5-HT3 receptors) and habituation to this environment (possibly mediated by postsynaptic 5-HT1A and 5-HT2 receptors).

Putative contribution of the serotonergic system to the effects of drugs of abuse

Serotonergic agents have been found to affect the neurochemical and behavioural response to drugs of abuse. These effects may well be the result of the fact that serotonergic agents can 
change the release of mesolimbic dopamine (Kilpatrick et al. 1996; De Deurwaerdere and Spampinato 1999; Ichikawa and Meltzer 2000). 5-HT3 antagonists are suggested to be effective in the treatment of alcohol abuse (Greenshaw 1993; Grant 1995), whereas 5-HT2A antagonists (McMahon and Cunningham 2001; Davidson et al. 2002; Filip et al. 2004; Bubar and Cunningham 2006) and 5-HT2C agonists (Fletcher et al. 2004; Filip et al. 2006; Bubar and Cunningham 2006; Neisewander and Acosta 2007) can reduce the behavioural effects of cocaine. Finally, systemic administration of 5-HT1A antagonists and agonists are known to, respectively, increase and reduce the accumbal dopamine response to cocaine and amphetamine (Ichikawa et al. 1995; Andrews et al. 2005). In case serotonergic agents can be used to treat drug abuse, personalised therapy is preferred. On the basis of our finding that rats being selected on a low and high response to novelty differ in their sensitivity to serotonergic agents, it is hypothesised that the optimal serotonergic therapy may differ between substance abusers with a low and a high sensation-seeking score.

\section{Conclusions}

HR and LR rats have been found to differ in the expression of 5-HT6 and 5-HT7 receptors (Ballaz et al. 2007a, c) as well as in the levels of serotonin in the brain (Piazza et al. 1991b). The present study provides the original finding that HR and LR rats also significantly differ in their sensitivity to serotonergic drugs that act at the level of 5HT3, 5-HT2 and 5-HT1 receptors (see Fig. 6). Future studies using HR and LR rats are required to investigate in which brain structures these receptors are located. Knowledge about the serotonergic system of high and low responders to novelty rats may well contribute to our knowledge about the serotonergic system of high and low sensation seekers in humans (Dellu et al. 1996; Ballaz et al. $2007 \mathrm{a}$, c). On the basis of our animal studies, it is hypothesised that the level of sensation seeking in humans can predict which subjects are vulnerable to a specific serotonergic therapy and which subjects are not.

Acknowledgements This work was partly financed by a special incentive of the Ministry of Education and Science, The Netherlands, to promote top research at the Department of Psychoneuropharmacology (PNF). The authors wish to thank Marline van Hoek, Marsja Meijer and Joost Lensen for technical assistance, Dick Heeren for advice on statistics and Judith Homberg for discussion. All experiments comply with the current laws of the Netherlands.

Open Access This article is distributed under the terms of the Creative Commons Attribution Noncommercial License which permits any noncommercial use, distribution, and reproduction in any medium, provided the original author(s) and source are credited.

\section{References}

Adell A, Casanovas JM, Artigas F (1997) Comparative study in the rat of the actions of different types of stress on the release of 5-HT in raphe nuclei and forebrain areas. Neuropharmacology 36:735-741

Andrews N, File SE (1992) Are there changes in sensitivity to 5-HT3 receptor ligands following chronic diazepam treatment? Psychopharmacology (Berl) 108:333-337

Andrews CM, Kung HF, Lucki I (2005) The 5-HT1A receptor modulates the effects of cocaine on extracellular serotonin and dopamine levels in the nucleus accumbens. Eur J Pharmacol 508:123-130

Ballaz SJ, Akil H, Watson SJ (2007a) Analysis of 5-HT6 and 5-HT7 receptor gene expression in rats showing differences in noveltyseeking behavior. Neuroscience 147:428-438

Ballaz SJ, Akil H, Watson SJ (2007b) Previous experience affects subsequent anxiety-like responses in rats bred for novelty seeking. Behav Neurosci 121:1113-1118

Ballaz SJ, Akil H, Watson SJ (2007c) The 5-HT7 receptor: role in novel object discrimination and relation to novelty-seeking behavior. Neuroscience 149:192-202

Barnes NM, Sharp T (1999) A review of central 5-HT receptors and their function. Neuropharmacology 38:1083-1152

Bolonna AA, Arranz MJ, Mancama D, Kerwin RW (2004) Pharmacogenomics: can genetics help in the care of psychiatric patients? Int Rev Psychiatry 16:311-319

Boothman LJ, Sharp T (2005) A role for midbrain raphe gamma aminobutyric acid neurons in 5-hydroxytryptamine feedback control. Neuroreport 16:891-896

Boothman LJ, Allers KA, Rasmussen K, Sharp T (2003) Evidence that central 5-HT2A and 5-HT2B/C receptors regulate 5-HT cell firing in the dorsal raphe nucleus of the anaesthetised rat. $\mathrm{Br} \mathrm{J}$ Pharmacol 139:998-1004

Brioni JD, O’Neill AB, Kim DJ, Buckley MJ, Decker MW, Arneric SP (1994) Anxiolytic-like effects of the novel cholinergic channel activator ABT-418. J Pharmacol Exp Ther 271:353-361

Bubar MJ, Cunningham KA (2006) Serotonin 5-HT2A and 5-HT2C receptors as potential targets for modulation of psychostimulant use and dependence. Curr Top Med Chem 6:1971-1985

Bull EJ, Hutson PH, Fone KC (2004) Decreased social behaviour following 3, 4-methylenedioxymethamphetamine (MDMA) is accompanied by changes in 5-HT2A receptor responsivity. Neuropharmacology 46:202-210

Cayetanot F, Gros F, Larnicol N (2001) 5-HT(2A/2C) receptormediated hypopnea in the newborn rat: relationship to Fos immunoreactivity. Pediatr Res 50:596-603

Chefer VI, Zakharova I, Shippenberg TS (2003) Enhanced responsiveness to novelty and cocaine is associated with decreased basal dopamine uptake and release in the nucleus accumbens: quantitative microdialysis in rats under transient conditions. J Neurosci 23:3076-3084

Coccaro EF (1989) Central serotonin and impulsive aggression. Br J Psychiatry 155:52-62

Collinson N, Dawson GR (1997) On the elevated plus-maze the anxiolytic-like effects of the 5-HT(1A) agonist, 8-OH-DPAT, but not the anxiogenic-like effects of the 5-HT(1A) partial agonist, buspirone, are blocked by the 5-HT1A antagonist, WAY 100635. Psychopharmacology (Berl) 132:35-43

Consolo S, Ladinsky H, Tirelli AS, Crunelli V, Samanin R, Garattini S (1979) Increase in rat striatal acetylcholine content by d-fenfluramine, a serotonin releaser. Life Sci 25:1975-1981

Consolo S, Bertorelli R, Russi G, Zambelli M, Ladinsky H (1994) Serotonergic facilitation of acetylcholine release in vivo from rat dorsal hippocampus via serotonin 5-HT3 receptors. J Neurochem 62:2254-2261 
Cools AR, Ellenbroek BA (1996) Wistar rats: splitting high and low responders to novelty is necessary in basal ganglia research. In: Ohye C, Kimura M (eds) The basal ganglia V. Plenum, New York, pp 493-498

Cools AR, Ellenbroek B (2002) Animal models of personality. In: D'Haenen H, den Boer JA, Willner P (eds) Biological psychiatry. Wiley, Chichester, pp 1333-1344

Cools AR, Gingras MA (1998) Nijmegen high and low responders to novelty: a new tool in the search after the neurobiology of drug abuse liability. Pharmacol Biochem Behav 60:151-159

Cools AR, Brachten R, Heeren D, Willemen A, Ellenbroek B (1990) Search after neurobiological profile of individual-specific features of Wistar rats. Brain Res Bull 24:49-69

Cools AR, Rots NY, Ellenbroek B, de Kloet ER (1993) Bimodal shape of individual variation in behavior of Wistar rats: the overall outcome of a fundamentally different make-up and reactivity of the brain, the endocrinological and the immunological system. Neuropsychobiology 28:100-105

Cools AR, Ellenbroek BA, Gingras MA, Engbersen A, Heeren D (1997) Differences in vulnerability and susceptibility to dexamphetamine in Nijmegen high and low responders to novelty: a dose-effect analysis of spatio-temporal programming of behaviour. Psychopharmacology (Berl) 132:181-187

Critchley MA, Handley SL (1987) Effects in the X-maze anxiety model of agents acting at 5-HT1 and 5-HT2 receptors. Psychopharmacology (Berl) 93:502-506

Davidson C, Lazarus C, Xiong X, Lee TH, Ellinwood EH (2002) 5HT2 receptor antagonists given in the acute withdrawal from daily cocaine injections can reverse established sensitization. Eur J Pharmacol 453:255-263

De Deurwaerdere P, Spampinato U (1999) Role of serotonin(2A) and serotonin $(2 \mathrm{~B} / 2 \mathrm{C})$ receptor subtypes in the control of accumbal and striatal dopamine release elicited in vivo by dorsal raphe nucleus electrical stimulation. J Neurochem 73:1033-1042

Dellu F, Piazza PV, Mayo W, Le Moal M, Simon H (1996) Noveltyseeking in rats-biobehavioral characteristics and possible relationship with the sensation-seeking trait in man. Neuropsychobiology 34:136-145

Dervaux A, Bayle FJ, Laqueille X, Bourdel MC, Le Borgne MH, Olie JP, Krebs MO (2001) Is substance abuse in schizophrenia related to impulsivity, sensation seeking, or anhedonia? Am J Psychiatry 158:492-494

Dos Santos L, De Andrade TG, Zangrossi HJ (2005) Serotonergic neurons in the median raphe nucleus regulate inhibitory avoidance but not escape behavior in the rat elevated T-maze test of anxiety. Psychopharmacology (Berl) 179:733-741

Dos-Santos L, De Andrade TG, Zangrossi-Junior H (2008) 5HT1A receptors in the dorsal hippocampus mediate the anxiogenic effect induced by the stimulation of 5-HT neurons in the median raphe nucleus. Eur Neuropsychopharmacol $18: 286-294$

Dunn RW, Corbett R, Fielding S (1989) Effects of 5-HT1A receptor agonists and NMDA receptor antagonists in the social interaction test and the elevated plus maze. Eur J Pharmacol 169:1-10

Ellenbroek BA, Cools AR (2002) Apomorphine susceptibility and animal models for psychopathology: genes and environment. Behav Genet 32:349-361

Ellenbroek BA, Geyer MA, Cools AR (1995) The behavior of APOSUS rats in animal models with construct validity for schizophrenia. J Neurosci 15:7604-7611

File SE, Zangrossi HJ, Viana M, Graeff FG (1993) Trial 2 in the elevated plus-maze: a different form of fear? Psychopharmacology (Berl) 111:491-494
Filip M, Baran L, Siwanowicz J, Chojnacka-Wojcik E, Przegalinski E (1992) The anxiolytic-like effects of 5-hydroxytryptamine3 (5HT3) receptor antagonists. Pol J Pharmacol Pharm 44:261-269

Filip M, Bubar MJ, Cunningham KA (2004) Contribution of serotonin (5-hydroxytryptamine; 5-HT) 5-HT2 receptor subtypes to the hyperlocomotor effects of cocaine: acute and chronic pharmacological analyses. J Pharmacol Exp Ther 310:1246-1254

Filip M, Bubar MJ, Cunningham KA (2006) Contribution of serotonin (5-HT) 5-HT2 receptor subtypes to the discriminative stimulus effects of cocaine in rats. Psychopharmacology (Berl) 183:482-489

Fletcher PJ, Chintoh AF, Sinyard J, Higgins GA (2004) Injection of the 5HT2C receptor agonist Ro60-0175 into the ventral tegmental area reduces cocaine-induced locomotor activity and cocaine selfadministration. Neuropsychopharmacology 29:308-318

Gargiulo PA, Viana MB, Graeff FG, Silva MA, Tomaz C (1996) Effects of anxiety and memory of systemic and intra-amygdala injection of 5-HT3 receptor antagonist BRL 46470A. Neuropsychobiology 33:189-195

Graeff FG, Guimaraes FS, De Andrade TG, Deakin JF (1996a) Role of 5-HT in stress, anxiety, and depression. Pharmacol Biochem Behav 54:129-141

Graeff FG, Viana MB, Mora PO (1996b) Opposed regulation by dorsal raphe nucleus 5-HT pathways of two types of fear in the elevated T-maze. Pharmacol Biochem Behav 53:171-177

Graeff FG, Viana MB, Mora PO (1997) Dual role of 5-HT in defense and anxiety. Neurosci Biobehav Rev 21:791-799

Graeff FG, Netto CF, Zangrossi HJ (1998) The elevated T-maze as an experimental model of anxiety. Neurosci Biobehav Rev 23:237246

Grant KA (1995) The role of 5-HT3 receptors in drug dependence. Drug Alcohol Depend 38:155-171

Greenshaw AJ (1993) Behavioural pharmacology of 5-HT3 receptor antagonists: a critical update on therapeutic potential. Trends Pharmacol Sci 14:265-270

Griebel G, Moreau JL, Jenck F, Martin JR, Misslin R (1993) Some critical determinants of the behavior of rats in the elevated plusmaze. Behav Processes 29:37-47

Gundlah C, Martin KF, Heal DJ, Auerbach SB (1997) In vivo criteria to differentiate monoamine reuptake inhibitors from releasing agents: sibutramine is a reuptake inhibitor. J Pharmacol Exp Ther 283:581-591

Hooks MS, Jones GH, Smith AD, Neill DB, Justice JB Jr (1991) Response to novelty predicts the locomotor and nucleus accumbens dopamine response to cocaine. Synapse 9:121-128

Hooks MS, Colvin AC, Juncos JL, Justice JB Jr (1992) Individual differences in basal and cocaine-stimulated extracellular dopamine in the nucleus accumbens using quantitative microdialysis. Brain Res 587:306-312

Ichikawa J, Meltzer HY (2000) The effect of serotonin(1A) receptor agonism on antipsychotic drug-induced dopamine release in rat striatum and nucleus accumbens. Brain Res 858:252-263

Ichikawa J, Kuroki T, Kitchen MT, Meltzer HY (1995) R(+)-8-OHDPAT, a 5-HT1A receptor agonist, inhibits amphetamine-induced dopamine release in rat striatum and nucleus accumbens. Eur J Pharmacol 287:179-184

Kabbaj M, Devine DP, Savage VR, Akil H (2000) Neurobiological correlates of individual differences in novelty-seeking behavior in the rat: differential expression of stress-related molecules. $\mathrm{J}$ Neurosci 20:6983-6988

Kabbaj M, Morley-Fletcher S, Le Moal M, Maccari S (2007) Individual differences in the effects of chronic prazosin hydrochloride treatment on hippocampal mineralocorticoid and glucocorticoid receptors. Eur J Neurosci 25:3312-3318

Kelly TH, Robbins G, Martin CA, Fillmore MT, Lane SD, Harrington NG, Rush CR (2006) Individual differences in drug abuse 
vulnerability: d-amphetamine and sensation-seeking status. Psychopharmacology (Berl) 189:17-25

Kilpatrick GJ, Hagan RM, Gale JD (1996) 5-HT3 and 5-HT4 receptors in terminal regions of the mesolimbic system. Behav Brain Res 73:11-13

Kshama D, Hrishikeshavan HJ, Shanbhogue R, Munonyedi US (1990) Modulation of baseline behavior in rats by putative serotonergic agents in three ethoexperimental paradigms. Behav Neural Biol 54:234-253

Laget J, Plancherel B, Stephan P, Bolognini M, Corcos M, Jeammet P, Halfon O (2006) Personality and repeated suicide attempts in dependent adolescents and young adults. Crisis 27:164-171

Landgraf R, Wigger A, Holsboer F, Neumann ID (1999) Hyper-reactive hypothalamo-pituitary-adrenocortical axis in rats bred for high anxiety-related behaviour. J Neuroendocrinol 11:405-407

Lane HY, Lee CC, Liu YC, Chang WH (2005) Pharmacogenetic studies of response to risperidone and other newer atypical antipsychotics. Pharmacogenomics 6:139-149

Lerer B, Macciardi F (2002) Pharmacogenetics of antidepressant and mood-stabilizing drugs: a review of candidate-gene studies and future research directions. Int J Neuropsychopharmacol 5:255-275

Liebsch G, Linthorst AC, Neumann ID, Reul JM, Holsboer F, Landgraf R (1998) Behavioral, physiological, and neuroendocrine stress responses and differential sensitivity to diazepam in two Wistar rat lines selectively bred for high- and low-anxietyrelated behavior. Neuropsychopharmacology 19:381-396

Liu R, Jolas T, Aghajanian G (2000) Serotonin 5-HT(2) receptors activate local GABA inhibitory inputs to serotonergic neurons of the dorsal raphe nucleus. Brain Res 873:34-45

McMahon LR, Cunningham KA (2001) Antagonism of 5hydroxytryptamine(2a) receptors attenuates the behavioral effects of cocaine in rats. J Pharmacol Exp Ther 297:357-363

McMahon FJ, Buervenich S, Charney D, Lipsky R, Rush AJ, Wilson AF, Sorant AJ, Papanicolaou GJ, Laje G, Fava M, Trivedi MH, Wisniewski SR, Manji H (2006) Variation in the gene encoding the serotonin 2A receptor is associated with outcome of antidepressant treatment. Am J Hum Genet 78:804-814

Mehlman PT, Higley JD, Faucher I, Lilly AA, Taub DM, Vickers J, Suomi SJ, Linnoila M (1994) Low CSF 5-HIAA concentrations and severe aggression and impaired impulse control in nonhuman primates. Am J Psychiatry 151:1485-1491

Mora PO, Netto CF, Graeff FG (1997) Role of 5-HT2A and 5-HT2C receptor subtypes in the two types of fear generated by the elevated T-maze. Pharmacol Biochem Behav 58:1051-1057

Neisewander JL, Acosta JI (2007) Stimulation of 5-HT2C receptors attenuates cue and cocaine-primed reinstatement of cocaineseeking behavior in rats. Behav Pharmacol 18:791-800

Netter P, Hennig J, Roed IS (1996) Serotonin and dopamine as mediators of sensation seeking behavior. Neuropsychobiology $34: 155-165$

Pascual J, Soler J, Baiget M, Cortes A, Menoyo A, Barrachina J, Ropero M, Goma M, Alvarez E, Perez V (2007) Association between the serotonin transporter gene and personality traits in borderline personality disorder patients evaluated with Zuckerman-Zuhlman Personality Questionnaire (ZKPQ). Actas Esp Psiquiatr 35:382-386

Patkar AA, Murray HW, Mannelli P, Gottheil E, Weinstein SP, Vergare MJ (2004) Pre-treatment measures of impulsivity, aggression and sensation seeking are associated with treatment outcome for African-American cocaine-dependent patients. J Addict Dis 23:109-122

Peng WH, Wu CR, Chen CS, Chen CF, Leu ZC, Hsieh MT (2004) Anxiolytic effect of berberine on exploratory activity of the mouse in two experimental anxiety models: interaction with drugs acting at 5-HT receptors. Life Sci 75:2451-2462
Piazza PV, Deminiere JM, Le Moal M, Simon H (1989) Factors that predict individual vulnerability to amphetamine selfadministration. Science 245:1511-1513

Piazza PV, Maccari S, Deminiere JM, Le Moal M, Mormede P, Simon H (1991a) Corticosterone levels determine individual vulnerability to amphetamine self-administration. Proc Natl Acad Sci U S A 88:2088-2092

Piazza PV, Rouge Pont F, Deminiere JM, Kharoubi M, Le Moal M, Simon H (1991b) Dopaminergic activity is reduced in the prefrontal cortex and increased in the nucleus accumbens of rats predisposed to develop amphetamine self-administration. Brain Res 567:169-174

Pickar D (2003) Pharmacogenomics of psychiatric drug treatment. Psychiatr Clin North Am 26:303-321 vii

Poncelet M, Perio A, Simiand J, Gout G, Soubrie P, Le Fur G (1995) Antidepressant-like effects of SR 57227A, a 5-HT3 receptor agonist, in rodents. J Neural Transm Gen Sect 102:83-90

Ranaldi R, Bauco P, McCormick S, Cools AR, Wise RA (2001) Equal sensitivity to cocaine reward in addiction-prone and addictionresistant rat genotypes. Behav Pharmacol 12:527-534

Roberti JW (2004) A review of behavioral and biological correlates of sensation seeking. J Res Pers 38:256-279

Rots NY, Cools AR, de Jong J, de Kloet ER (1995) Corticosteroid feedback resistance in rats genetically selected for increased dopamine responsiveness. J Neuroendocrinol 7:153-161

Rots NY, Cools AR, Oitzl MS, de Jong J, Sutanto W, de Kloet ER (1996) Divergent prolactin and pituitary-adrenal activity in rats selectively bred for different dopamine responsiveness. Endocrinology 137:1678-1686

Saigusa T, Tuinstra T, Koshikawa N, Cools AR (1999) High and low responders to novelty: effects of a catecholamine synthesis inhibitor on novelty-induced changes in behaviour and release of accumbal dopamine. Neuroscience 88:1153-1163

Schreiber R, Melon C, De Vry J (1998) The role of 5-HT receptor subtypes in the anxiolytic effects of selective serotonin reuptake inhibitors in the rat ultrasonic vocalization test. Psychopharmacology (Berl) 135:383-391

Sena LM, Bueno C, Pobbe RL, Andrade TG, Zangrossi HJ, Viana MB (2003) The dorsal raphe nucleus exerts opposed control on generalized anxiety and panic-related defensive responses in rats. Behav Brain Res 142:125-133

Serrats J, Mengod G, Cortes R (2005) Expression of serotonin 5HT2C receptors in GABAergic cells of the anterior raphe nuclei. J Chem Neuroanat 29:83-91

Sonavane GS, Sarveiya VP, Kasture VS, Kasture SB (2002) Anxiogenic activity of Myristica fragrans seeds. Pharmacol Biochem Behav 71:239-244

Thiel CM, Muller CP, Huston JP, Schwarting RK (1999) High versus low reactivity to a novel environment: behavioural, pharmacological and neurochemical assessments. Neuroscience 93:243-251

Thomas H, Fink H, Sohr TR, Voits M (2000) Lesion of the median raphe nucleus: a combined behavioral and microdialysis study in rats. Pharmacol Biochem Behav 65:15-21

Treit D, Robinson A, Rotzinger S, Pesold C (1993) Anxiolytic effects of serotonergic interventions in the shock-probe burying test and the elevated plus-maze test. Behav Brain Res 54:23-34

Tuinstra T, Verheij M, Willemen A, Iking J, Heeren DJ, Cools AR (2000) Retrieval of spatial information in Nijmegen high and low responders: involvement of beta-adrenergic mechanisms in the nucleus accumbens. Behav Neurosci 114:1088-1095

Verheij MM, Cools AR (2007) Differential contribution of storage pools to the extracellular amount of accumbal dopamine in high and low responders to novelty: effects of reserpine. J Neurochem $100: 810-821$ 
Verheij MM, Cools AR (2008) Twenty years of dopamine research: Individual differences in the response of accumbal dopamine to environmental and pharmacological challenges. Eur J Pharmacol 585:228-244

Verheij MM, Peters R, Spiegelberg L, de Mulder E, Cools AR (2007) In vivo rat approach to discover potential new anti-Parkinson agents such as SKF83959 that lack unwanted side-effects in MPTP-lesioned Rhesus monkeys. Ninth International Basal Ganglia Society meeting, Egmond aan Zee, The Netherlands Program No. 110

Verheij MM, De Mulder EL, De Leonibus E, Van Loo KM, Cools AR (2008) Rats that differentially respond to cocaine differ in their dopaminergic storage capacity of the nucleus accumbens. J Neurochem 105:2122-2133

Viana MB, Tomaz C, Graeff FG (1994) The elevated T-maze: a new animal model of anxiety and memory. Pharmacol Biochem Behav 49:549-554

Viana MB, Graeff FG, Loschmann PA (1997) Kainate microinjection into the dorsal raphe nucleus induces 5-HT release in the amygdala and periaqueductal gray. Pharmacol Biochem Behav $58: 167-172$
Viana MB, Zangrossi HJ, Onusic GM (2008) 5-HT1A receptors of the lateral septum regulate inhibitory avoidance but not escape behavior in rats. Pharmacol Biochem Behav 89:360366

Vicente MA, Zangrossi HJ, Dos-Santos L, de Macedo CE, Andrade TG (2008) Involvement of median raphe nucleus 5 -HT(1A) receptors in the regulation of generalized anxietyrelated defensive behaviours in rats. Neurosci Lett 445:204208

Zangrossi HJ, Viana MB, Zanoveli J, Bueno C, Nogueira RL, Graeff FG (2001) Serotonergic regulation of inhibitory avoidance and one-way escape in the rat elevated T-maze. Neurosci Biobehav Rev 25:637-645

Zuckerman M (1993) P-impulsive sensation seeking and its behavioral, psychophysiological and biochemical correlates. Neuropsychobiology 28:30-36

Zuckerman M (1996) The psychobiological model for impulsive unsocialized sensation seeking: a comparative approach. Neuropsychobiology 34:125-129

Zuckerman M, Neeb M (1979) Sensation seeking and psychopathology. Psychiatry Res 1:255-264 